\title{
Sequential Non-Saccharomyces and Saccharomyces cerevisiae Fermentations to Reduce the Alcohol Content in Wine
}

\author{
Margarita García $^{1}\left(\mathbb{D}\right.$, Braulio Esteve-Zarzoso ${ }^{2} \mathbb{D}$, Juan Mariano Cabellos ${ }^{1}$ (D) and \\ Teresa Arroyo 1,*(D) \\ 1 Department of Food and Agricultural Science, IMIDRA, 28800 Alcalá de Henares, Spain; \\ margarita_garcia_garcia@madrid.org (M.G.); juan.cabellos@madrid.org (J.M.C.) \\ 2 Department of Chemistry and Biotechnology, Rovira i Virgili University, 43007 Tarragona, Spain; \\ braulio.esteve@urv.cat \\ * Correspondence: teresa.arroyo@madrid.org; Tel.: +34-918-879-486
}

Received: 21 May 2020; Accepted: 7 June 2020; Published: 10 June 2020

\begin{abstract}
Over the last decades, the average alcohol content of wine has increased due to climate change and consumer preferences for particular wine styles that resulted in increased grape sugar levels at harvest. Therefore, alcohol reduction is a current challenge in the winemaking industry. Among several strategies under study, the use of non-conventional yeasts in combination with Saccharomyces cerevisiae plays an important role for lowering ethanol production in wines nowadays. In the present work, 33 native non-Saccharomyces strains were assayed in sequential culture with a $S$. cerevisiae wine strain to determine their potential for reducing the alcohol content in Malvar white wines. Four of the non-Saccharomyces strains (Wickerhamomyces anomalus 21A-5C, Meyerozyma guilliermondii CLI 1217, and two Metschnikowia pulcherrima (CLI 68 and CLI 460)) studied in sequential combination with $S$. cerevisiae CLI 889 were best able to produce dry wines with decreased alcohol proportion in comparison with one that was inoculated only with $S$. cerevisiae. These sequential fermentations produced wines with between $0.8 \%(v / v)$ and $1.3 \%(v / v)$ lower ethanol concentrations in Malvar wines, showing significant differences compared with the control. In addition, these combinations provided favorable oenological characteristics to wines such as high glycerol proportion, volatile higher alcohols, and esters with fruity and sweet character.
\end{abstract}

Keywords: alcohol reduction; native yeast; non-Saccharomyces; sequential fermentation; wine

\section{Introduction}

At present, the increasing alcohol content in wines is closely related to climate change and consumer choice for full-bodied, rich, and ripe fruit flavor profiles, which often involve increased grape maturity [1-3]. In recent years, the worldwide trend towards more frequent warm periods during the grapevine growing season has increased sugar content in grapes and therefore the alcohol concentration in wines [4]. Thus, the average alcohol level has risen about $2 \%(v / v)$ over the past few decades in warm areas, and it is not uncommon to find wines with an alcohol content higher than $16 \%(v / v)$ [5]. Excessive alcohol concentration in wines can alter the sensory profile of wines, increasing bitterness, astringency, and hotness perception and masking some volatile compounds [6,7]. Additionally, wines with elevated alcohol content can lead to harmful health effects [8] and also increase costs in markets where taxes are linked to the ethanol level in many countries [9].

Among the various methodologies aimed at the reduction of alcohol content in wines, microbiological approaches may be promising to preserve organoleptic characteristics and quality in wines. In addition, they are profitable and easy to implement strategies that do not require the need 
for specialized equipment $[10,11]$. Saccharomyces cerevisiae is the principal microorganism selected for winemaking. This species completes fermentation of sugars due to its ability to produce and tolerate high concentrations of alcohol $[12,13]$. Unlike S. cerevisiae, non-Saccharomyces yeasts are not generally able to complete the fermentation process; thus, mixed or sequential inoculations with $S$. cerevisiae are required for this purpose [14-17]. Research efforts have therefore focused on developing new S. cerevisiae strains that produce less ethanol in wine [18] and on using non-Saccharomyces yeasts that metabolize sugar without producing ethanol or that do so with less efficiency [19].

Several investigations have employed non-Saccharomyces co-cultures as a tool for reducing the ethanol concentration in wine [19-29]. Here, the early inoculation of non-Saccharomyces strain transforms sugar to produce biomass and by-products, decreasing ethanol formation before addition of S. cerevisiae $[2,30]$. This action plan is particularly adequate to winemaking in warm regions, as in the case of the Madrid winegrowing region (Spain) under study in the present work. The climate in the Denomination of Origin (D.O.) "Vinos de Madrid" presents temperatures ranging from $-8{ }^{\circ} \mathrm{C}$ in winter to $41^{\circ} \mathrm{C}$ in summer, and rainfall ranges between 461 and $658 \mathrm{~mm}$ [31]. Winemakers in this region are working hard in order to elaborate new styles of wine that are more competitive in the market [32]. The knowledge and selection of native yeasts is a very important achievement to confer typicity and originality to the wine [33,34], and its use is also considered a reactive adaptation practice to climate change [35].

In this work, 33 native non-Saccharomyces strains from 13 different wine yeast species were tested with the aim of identifying yeasts that, in sequential fermentation with $S$. cerevisiae, could be used for reducing alcohol content in Malvar white wines, and additionally evaluating their positive impact on the quality of these wines. Moreover, no previous investigations have been carried out to select non-Saccharomyces/S. cerevisiae combinations with native yeasts from D.O. "Vinos de Madrid" (Madrid, Spain) directed towards ethanol reduction in wines.

\section{Materials and Methods}

\subsection{Yeast Strains: Purity and Identity Control}

A total of 33 non-Saccharomyces strains from the IMIDRA collection belonging to 10 different genera were used in this study (Table 1). All non-Saccharomyces strains were native from D.O. "Vinos de Madrid" vineyards and cellars $[31,36]$. The well-studied native strain, S. cerevisiae CLI 889, was employed as a control $[31,34,37]$. Cryogenically preserved $\left(-80^{\circ} \mathrm{C}\right)$ strains in $30 \%$ glycerol were subsequently seeded on YPD liquid medium (1\% yeast extract, $1 \%$ meat peptone, and $2 \%$ glucose (Conda Laboratories, Madrid, Spain), w/v) and incubated for $24-48 \mathrm{~h}$ at $28^{\circ} \mathrm{C}$. Later, all strains were maintained at $4{ }^{\circ} \mathrm{C}$ on YPD plates.

To confirm yeast strain identifications, DNA extraction and rDNA 5.8S-ITS region PCR-RFLP analysis [38] were employed as described previously by Cordero-Bueso et al. [39]. Some of these strains were also sequenced [31,40], and the D1/D2 domain of the 26S rDNA gene was amplified using primers NL-1 and NL-4 [41].

Table 1. Yeast strains used in this study.

\begin{tabular}{|c|c|c|c|c|}
\hline Species Name & Strain Code & Year of Isolation & Origin ${ }^{1}$ & References $^{2}$ \\
\hline \multirow{5}{*}{$\begin{array}{l}\text { Wickerhamomyces } \\
\text { anomalus }\end{array}$} & CLI 1218 & 2007 & Malvar ${ }^{a}$ & {$[31,36]$} \\
\hline & $31-1 C$ & 2006 & Garnacha $^{\mathrm{c}}$ & This study \\
\hline & $21 \mathrm{~A}-5 \mathrm{C}$ & 2007 & Garnacha $^{c}$ & [36] \\
\hline & $23 \mathrm{~A}-6 \mathrm{C}$ & 2007 & Garnacha ${ }^{\mathrm{c}}$ & [36] \\
\hline & $5 B-1 C$ & 2008 & Garnacha $^{\mathrm{c}}$ & This study \\
\hline \multirow{2}{*}{ Candida stellata } & $6-5 \mathrm{~A}$ & 2006 & Shiraz ${ }^{c}$ & [36] \\
\hline & $2 \mathrm{~A}-1 \mathrm{~B}$ & 2007 & Shiraz ${ }^{\mathrm{c}}$ & This study \\
\hline
\end{tabular}


Table 1. Cont.

\begin{tabular}{|c|c|c|c|c|}
\hline Species Name & Strain Code & Year of Isolation & Origin ${ }^{1}$ & References $^{2}$ \\
\hline \multirow{2}{*}{ Hanseniaspora valbyensis } & CLI 194 & 1993 & Garnacha $^{a}$ & [36] \\
\hline & CLI 190 & 1993 & Garnacha $^{\text {a }}$ & [36] \\
\hline \multirow{5}{*}{$\begin{array}{l}\text { Hanseniaspora } \\
\text { guilliermondii }\end{array}$} & CLI 417 & 1995 & Malvar ${ }^{a}$ & This study \\
\hline & 7A-3A & 2007 & Garnacha $^{c}$ & This study \\
\hline & $8 \mathrm{~A}-8 \mathrm{~B}$ & 2007 & Garnacha ${ }^{c}$ & This study \\
\hline & CLI 225 & 1994 & Tempranillo $^{\text {a }}$ & {$[36,42]$} \\
\hline & CLI 72 & 1993 & Garnacha $^{\mathrm{a}}$ & [36] \\
\hline Hanseniaspora uvarum & CLI 903 & 1993 & Airén ${ }^{b}$ & {$[36,42]$} \\
\hline Hanseniaspora vineae & CLI 3 & 1993 & Tempranillo $^{a}$ & [36] \\
\hline \multirow{3}{*}{ Torulaspora delbrueckii } & LS1 FF2 3A & 2009 & Garnacha $^{a}$ & [33] \\
\hline & LS2 FF2 1A & 2009 & Garnacha $^{\text {a }}$ & [33] \\
\hline & CLI 918 & 2006 & Malvar $^{\mathrm{a}}$ & {$[16,40,42,43]$} \\
\hline \multirow{6}{*}{$\begin{array}{c}\text { Metschnikowia } \\
\text { pulcherrima }\end{array}$} & CLI 68 & 1993 & Garnacha $^{\text {a }}$ & [36] \\
\hline & CLI 457 & 1995 & Malvar $^{\mathrm{a}}$ & {$[16,36,40,42]$} \\
\hline & CLI 463 & 1995 & Malvar ${ }^{a}$ & This study \\
\hline & CLI 219 & 1994 & Malvar ${ }^{a}$ & {$[36,42]$} \\
\hline & CLI 460 & 1995 & Malvar a & {$[36,42]$} \\
\hline & CLI 461 & 1995 & Malvar a & This study \\
\hline \multirow{4}{*}{ Lachancea thermotolerans } & AMB FF4 10A & 2009 & Malvar ${ }^{a}$ & [33] \\
\hline & $3-4 \mathrm{~A}$ & 2006 & Shiraz ${ }^{\mathrm{c}}$ & [36] \\
\hline & $9-6 C$ & 2006 & Malvar ${ }^{a}$ & {$[16,40,42]$} \\
\hline & CLI 1219 & 2007 & Malvar $^{a}$ & {$[31,42]$} \\
\hline Pichia membranifaciens & CLI 679 & 2006 & Malvar ${ }^{a}$ & {$[31,42]$} \\
\hline $\begin{array}{l}\text { Meyerozyma } \\
\text { guilliermondii }\end{array}$ & CLI 1217 & 2006 & Malvar $^{a}$ & {$[31,42]$} \\
\hline Priceomyces carsonii & CLI 1221 & 2006 & Malvar $^{\mathrm{a}}$ & {$[31,42]$} \\
\hline Zygosaccharomyces bailii & CLI 622 & 2009 & Malvar $^{\mathrm{a}}$ & {$[31,42]$} \\
\hline Saccharomyces cerevisiae & CLI 889 & 2000 & Airén ${ }^{a}$ & {$[16,34,37,40,42,43]$} \\
\hline
\end{tabular}

${ }^{1} \mathrm{a}$, spontaneous fermentation; $\mathrm{b}$, must; $\mathrm{c}$, grape; ${ }^{2}$ publications in which strains have been investigated.

\subsection{Laboratory-Scale Fermentations}

Bunches from healthy grapes of white Malvar (Vitis vinifera L. cv.) variety were collected from a vineyard in the Madrid winegrowing region of Spain $\left(40^{\circ} 31^{\prime} \mathrm{N}, 3^{\circ} 17^{\prime} \mathrm{W}\right.$ and $610 \mathrm{~m}$ altitude). The must was clarified by pectolytic enzymes (Enozym Altair, Agrovin, Spain) $(0.01 \mathrm{~g} / \mathrm{L})$ at $4{ }^{\circ} \mathrm{C}$ and stored frozen until use. The main characteristics of Malvar must were $\mathrm{pH} 3.3 ; 23.3^{\circ}$ Brix, equivalent to about $230 \mathrm{~g} / \mathrm{L}$ of reducing sugars; probable alcohol content, $13.5 \%(v / v)$; and yeast assimilable nitrogen (YAN), $170 \mathrm{mg} / \mathrm{L}$.

The grape must was inoculated with a final concentration of $10^{6}$ cells $/ \mathrm{mL}$ from $48 \mathrm{~h}$ pre-cultures of each yeast strain (33 non-Saccharomyces and 1 S. cerevisiae as control strain). The fermentations were carried out in quadruplicate in $50 \mathrm{~mL}$ Falcon tubes containing $30 \mathrm{~mL}$ of sterile Malvar must. The trials were divided into two sections: Section I (pure culture), where strain growth was performed in aerobic conditions at $20^{\circ} \mathrm{C}$ with continuous orbital shaking $(130 \mathrm{rpm})$. The fermentation kinetic was controlled daily by weight loss. At $96 \mathrm{~h}$, one duplicate of each trial was used to the study of dry weight, residual sugars (glucose + fructose), and volatile acidity (as g/L of acetic acid); and Section II (sequential culture), the other duplicate from Section I, was inoculated with $10^{6}$ cells $/ \mathrm{mL}$ S. cerevisiae CLI 889. In this case, Falcon tubes hermetically sealed and fitted with air locks ensured anaerobic conditions. The fermentation process was conducted at $20{ }^{\circ} \mathrm{C}$ with shaking at $130 \mathrm{rpm}$ and was monitored daily until constant weight. Then, wine analyses were carried out. 
Dry cell weight measurements were performed on samples from sections I and II. The wine samples were centrifuged $(10,000 \mathrm{rpm}, 5 \mathrm{~min})$ and the pellets were washed with deionized water twice. Finally, dry weight was determined by filtering through a $0.45 \mu \mathrm{m}$ pore size membrane filter (Millipore). Filters were heat-dried at $105^{\circ} \mathrm{C}$ until constant weight was obtained.

\subsection{Analitycal Determination of Wines}

The concentration of glucose, fructose, glycerol, ethanol, and organic acids (malic, lactic, and acetic acids) was determined using a Waters 600E HPLC system (Waters, Milford, MA) at the end of fermentation. The HPLC was equipped with a Waters 2414 refractive index (RI) and Waters 2996 photodiode array detector (PDA) on a Rezex RHM-Monosaccharide $\mathrm{H}+(8 \%)$ column $(300 \times 7.8 \mathrm{~mm}$, Phenomenex, Torrance, CA, USA). The column was maintained at $65^{\circ} \mathrm{C}$, and $5 \mathrm{mM} \mathrm{H}_{2} \mathrm{SO}_{4}$ was used as mobile phase at a flow rate of $0.6 \mathrm{~mL} / \mathrm{min}$. In wine samples at $96 \mathrm{~h}$, only residual sugars (glucose + fructose) and volatile acidity (as $\mathrm{g} / \mathrm{L}$ of acetic acid) were measured with a multi analyzer LISA 200 (TDI, Barcelona, Spain), using enzymatic kits (TDI, Barcelona, Spain).

Quantification of major volatile compounds of wines was achieved using the gas chromatography coupled to flame ionization detector (GC-FID) technique. The GC system employed was an Agilent 6850 with a FID detector equipped with a column DB-Wax $(60 \mathrm{~m} \times 0.32 \mathrm{~mm} \times 0.5 \mu \mathrm{m}$ film thickness $)$ from J\&W Scientific (Folsom, CA, USA). The extraction and analysis methodologies of volatile analytes were performed following the procedure described by Ortega et al. [44]. Identification and quantification of the 32 individual major volatiles was performed using commercial pure standards. Calibration curves were drawn for each standard at 6 different concentration levels. Each standard was prepared in a synthetic wine solution $(5 \mathrm{~g} / \mathrm{L}$ of tartaric acid, dissolved in $13 \%$ of ethanol solution $(v / v)$, at $\mathrm{pH} 3.4$ adjusted with $\mathrm{NaOH})$. The obtained coefficients of regression $\left(R^{2}\right)$ were $>0.990[32,45]$.

\subsection{Statistical Treatment of Data}

The data were analyzed with SPSS Statistics 25 software (SPSS Inc., Chicago, IL, USA). Analysis of variance was carried out by ANOVA Tukey's test to examine significant differences between samples. Thus, a principal component analysis (PCA) was used to study the contribution of oenological and aromatic variables to the differences between Malvar wines.

\section{Results}

The genetic identification of the 33 non-Saccharomyces strains from vineyards and cellars of D.O. "Vinos de Madrid" allowed them to be classified into 13 species belonging to 10 different genera. The initial strain selection was designed to include species frequently isolated from the winemaking environment. Moreover, our strategy for ethanol reduction was the use of one non-Saccharomyces strain that exhibited a low ethanol yield but consumed enough sugars to affect the ethanol concentration (Section I) and be compatible with S. cerevisiae in order to ensure the completion of fermentation (Section II).

\subsection{Section I: Pure Culture of Non-Saccharomyces Strains}

In this section of the work, we studied fermentative kinetics of non-Saccharomyces strains and the control strain (S. cerevisiae CLI 889) in pure cultures. The fermentative profiles during the first $96 \mathrm{~h}$ permitted the division of the strains into three different groups: A, B, and C (Figure 1). Group A was represented by four non-Saccharomyces species: Wickerhamomyces anomalus (two strains), Candida stellata (one strain), Lachancea thermotolerans (one strain), and Hanseniaspora guilliermondii (two strains), which showed similar $\mathrm{CO}_{2}$ released to S. cerevisiae CLI 889 control strain. Group B included all Torulaspora delbrueckii and Hanseniaspora valbyensis strains studied in this work together with the other three $L$. thermotolerans strains. These strains showed less fermentative capacity than the control, with a $\mathrm{CO}_{2}$ loss between 2.2-1.2 g against above $3 \mathrm{~g}$ liberated by S. cerevisiae CLI 889 . Nine different non-Saccharomyces species were represented within group C. This latter group had 19 of 
33 non-Saccharomyces strains studied, wherein their fermentation kinetics presented the lowest $\mathrm{CO}_{2}$ liberation observed during the first $96 \mathrm{~h}$.
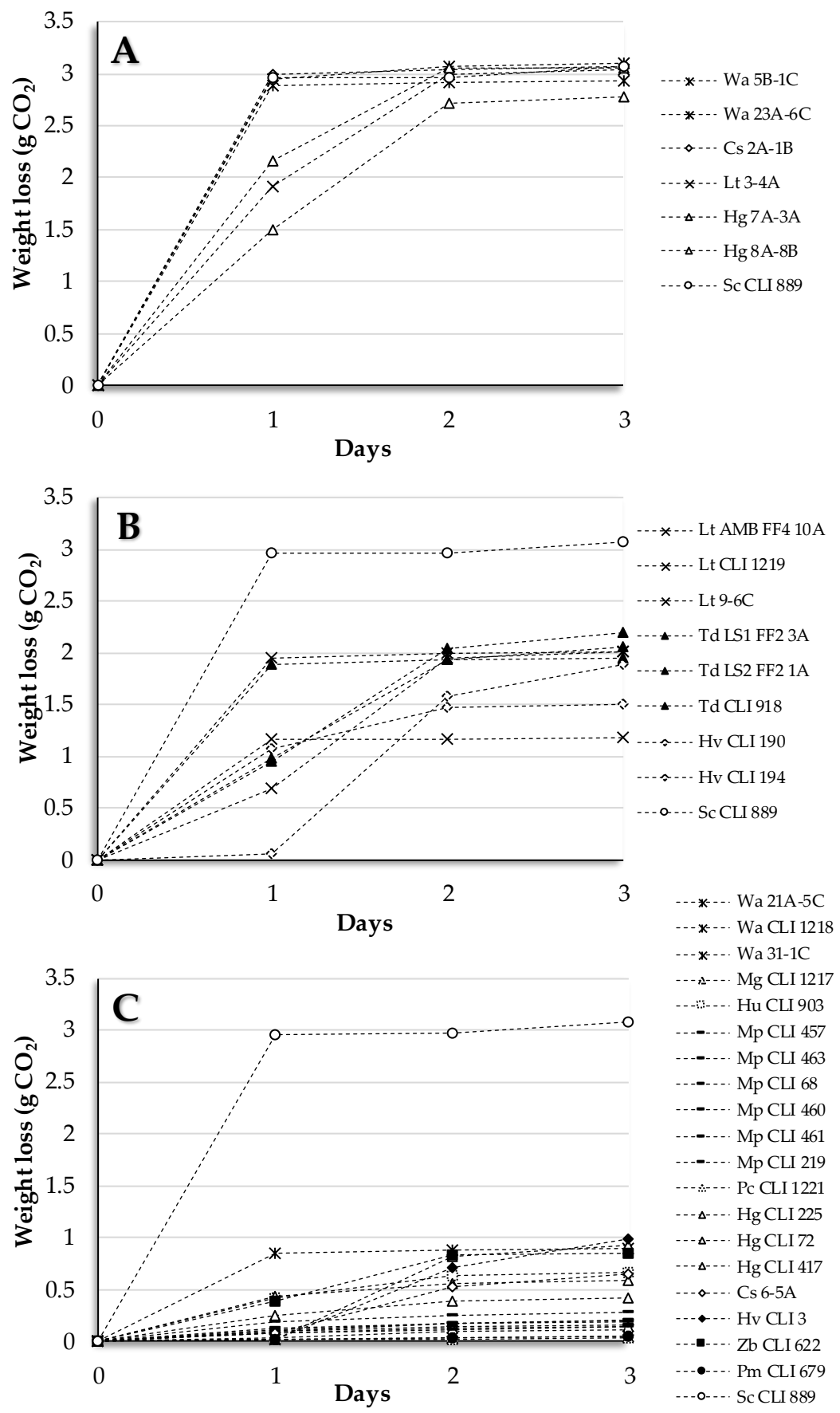

Figure 1. Release of $\mathrm{CO}_{2}$ in aerobic conditions. (A) Six non-Saccharomyces strains showed similar $\mathrm{CO}_{2}$ released to Sc CLI 889 control strain (white circles). (B) Eight non-Saccharomyces strains showed less $\mathrm{CO}_{2}$ released than the control (white circles). (C) Nineteen non-Saccharomyces strains showed values below 1 $\mathrm{g}$ of $\mathrm{CO}_{2}$ liberated from the control (white circles). Wa, W. anomalus; $\mathrm{Cs}, \mathrm{C}$. stellata; $\mathrm{Lt}, \mathrm{L}$. thermotolerans; $\mathrm{Hg}$, H. guilliermondii; Sc, S. cerevisiae; Td, T. delbrueckii; Hv, H. valbyensis; Mg, M. guilliermondii; $\mathrm{Hu}$, H. uvarum; Mp, M. pulcherrima; $\mathrm{Pc}$, P. carsonii; $\mathrm{Hv}$, H. vineae; Zb, Z. bailii; $\mathrm{Pm}$, P. membranifaciens. 


\subsection{Section II: Sequential Culture of Non-Saccharomyces/S. cerevisiae Strains}

After 96 h, S. cerevisiae CLI 889 was sequentially inoculated into all fermentations in Section I. A total of 8 days were needed by yeast strains to complete the fermentation process (Sections I and II).

Yeast isolates with fermentation behavior showing in group A (Section I) did not exhibit an increase on the $\mathrm{CO}_{2}$ release, producing similar amounts of ethanol at the end of fermentation-all of these wines were about $13 \%(v / v)$.

When sequential fermentations finished, some strains combinations produced wines with ethanol concentration similar to the control $(13 \%, v / v)$, and thus they were discarded as low-ethanol cultures. These sequential combinations that were not selected included the strains CLI 679, CLI 1218, 31-1C, CLI 457, CLI 72, CLI 219, CLI 461, CLI 463, CLI 1221, and CLI 903; all of them were classified into group C (Section I). Another group of non-Saccharomyces/S. cerevisiae fermentations, including CLI 918, CLI 194, CLI 1219, AMB FF4 10A, CLI 190, and LS1 FF2 3A strains from group B (Section I), and CLI 225, CLI 622, CLI 417, 6-5A, and CLI 3 strains from group C (Section I), increased by between 7\% and $10 \%$ in terms of ethanol concentration, but high amounts of residual sugars were not fermented, and thus these combinations were not selected either; most of them belonged to group B (Section I) in which $\mathrm{CO}_{2}$ liberated was lower than the control with values between 1.18 and 2.19 g. Finally, four non-Saccharomyces/S. cerevisiae sequential inoculations produced wines with decreased ethanol proportions compared with the control, and the residual sugars values were suitable for dry wines ( $<5 \mathrm{~g} / \mathrm{L}$ residual sugar) (Table 2$)$.

Table 2. Oenological parameters and cell dry weight for the best non-Saccharomyces/S. cerevisiae sequential combinations to reduce ethanol concentration in wines.

\begin{tabular}{|c|c|c|c|c|c|}
\hline \multirow[t]{2}{*}{ Parameters } & \multicolumn{5}{|c|}{ Yeast Culture } \\
\hline & Wa 21A-5C(S) & Mp CLI 68(S) & Mg CLI 1217(S) & Mp CLI 460(S) & Sc CLI 889(P) \\
\hline Malic acid (g/L) & $0.66 \pm 0.12^{a}$ & $0.60 \pm 0.02^{a}$ & $0.64 \pm 0.02^{a}$ & $0.45 \pm 0.09^{a}$ & $0.55 \pm 0.02^{\mathrm{a}}$ \\
\hline Lactic acid (g/L) & $2.10 \pm 0.26^{\mathrm{a}}$ & $2.48 \pm 0.30^{\mathrm{a}}$ & $2.50 \pm 0.23^{a}$ & $2.22 \pm 0.53^{a}$ & $2.31 \pm 0.02^{\mathrm{a}}$ \\
\hline Acetic acid (g/L) & $0.77 \pm 0.08^{a}$ & $0.86 \pm 0.01^{\mathrm{ab}}$ & $0.78 \pm 0.01^{\mathrm{ab}}$ & $0.71 \pm 0.16^{\mathrm{a}}$ & $0.43 \pm 0.00^{\text {ac }}$ \\
\hline Glucose (g/L) & $2.45 \pm 0.30^{\mathrm{a}}$ & $2.80 \pm 0.54^{\mathrm{a}}$ & $2.04 \pm 0.39^{a}$ & $2.97 \pm 0.53^{\mathrm{a}}$ & $2.70 \pm 0.01^{\mathrm{a}}$ \\
\hline Fructose (g/L) & $1.06 \pm 0.10^{\mathrm{a}}$ & $2.72 \pm 0.60^{b}$ & $0.69 \pm 0.04^{\mathrm{ac}}$ & $1.93 \pm 0.29^{a b}$ & $1.01 \pm 0.02^{\mathrm{a}}$ \\
\hline Glycerol (g/L) & $7.83 \pm 0.31^{\mathrm{a}}$ & $8.32 \pm 0.10^{a}$ & $7.06 \pm 0.61^{\mathrm{ab}}$ & $9.30 \pm 0.90^{\mathrm{ac}}$ & $7.60 \pm 0.02^{\mathrm{a}}$ \\
\hline Alcohol degree (\%) & $12.05 \pm 0.12^{\mathrm{a}}$ & $11.75 \pm 0.05^{\mathrm{a}}$ & $11.77 \pm 0.32^{a}$ & $12.16 \pm 0.26^{\mathrm{a}}$ & $13.00 \pm 0.01^{b}$ \\
\hline Dry weight (mg) & $4.35 \pm 0.07^{\mathrm{a}}$ & $3.73 \pm 0.08^{a}$ & $4.77 \pm 0.57^{\mathrm{ab}}$ & $3.28 \pm 0.61^{\mathrm{a}}$ & $2.95 \pm 0.01^{\mathrm{ac}}$ \\
\hline
\end{tabular}

\subsection{Yeast Strain Sequential Combinations Selected as Low-Ethanol Producers}

In order to reduce the ethanol content in wines, the selected non-Saccharomyces yeast strains were W. anomalus 21A-5C, Metschnikowia pulcherrima CLI 68, Meyerozyma guilliermondii CLI 1217, and M. pulcherrima CLI 460 used in sequential combination with S. cerevisiae CLI 889. These co-cultures produced wines with between $0.8 \%(v / v)$ and $1.3 \%(v / v)$ lower ethanol concentrations in Malvar wines, showing significant differences from the control (Table 2).

Sequential cultures inoculated with 21A-5C, CLI 68, and CLI 460 produced more glycerol than the control, highlighting M. pulcherrima CLI 460 strain with values significantly higher than the control (Table 2). There were no significantly differences in malic and lactic acid content, and fermentations with sequential combinations generated more acetic acid than the amount produced by the $S$. cerevisiae control (Table 2). Regarding dry weight, all sequential fermentations presented greater values compared with the control; in particular, sequential culture of M. guilliermondii CLI 1217 was 1.6-fold higher, showing significant differences (Table 2).

To find the aromatic composition of these wines, we studied 32 volatile compounds classified in alcohols, esters, acids, and aldehydes/ketones (Table 3). Sequential inoculation produced Malvar wines with greater total concentration of higher alcohols. The amounts of isoamyl alcohol (harsh, 
bitter) and $\beta$-phenylethyl alcohol (flowery, roses) were significantly higher in wines produced in sequential culture, increasing the total concentration of alcohols. The ethyl isovalerate and isoamyl acetate ester concentration responsible for fruity and sweet aromas were significantly different in wines generated from sequential inoculations. Regarding volatile acids, isobutyric acid and hexanoic acid were the main compounds responsible for the total concentration of volatile acids in all wines. The sequential culture $W$. anomalus 21A-5C/S. cerevisiae CLI 889 produced the highest concentration of the ketone acetoin. Finally, sequential cultures with M. pulcherrima strains (CLI 68 and CLI 460) and the control showed higher amounts of $\gamma$-butyrolactone, related to sweet aroma in wines.

Table 3. Major volatile compounds (mg/L) of wines produced in the Section II (sequential culture of non-Saccharomyces strains + S. cerevisiae CLI 889 and a control, S. cerevisiae CLI 889 pure culture).

\begin{tabular}{|c|c|c|c|c|c|}
\hline Compound & Wa 21A-5C(S) & Mp CLI 68(S) & Mg CLI 1217(S) & Mp CLI 460(S) & Sc CLI 889(P) \\
\hline 1-Propanol & n.q. & n.q. & n.q. & n.q. & $3.69 \pm 0.13^{a}$ \\
\hline 1-Butanol & $1.81 \pm 0.14^{\mathrm{a}}$ & $0.50 \pm 0.05^{b}$ & $0.46 \pm 0.05^{b}$ & $0.48 \pm 0.12^{b}$ & $0.40 \pm 0.10^{b}$ \\
\hline Isobutanol & $31.96 \pm 1.31^{\mathrm{a}}$ & $33.51 \pm 4.11^{\mathrm{a}}$ & $30.51 \pm 1.28^{a}$ & $49.46 \pm 0.24^{b}$ & $26.30 \pm 0.95^{\mathrm{a}}$ \\
\hline Isoamyl alcohol & $118.13 \pm 1.88^{a}$ & $114.56 \pm 5.92 \mathrm{ab}$ & $122.03 \pm 0.33^{a}$ & $106.47 \pm 0.53^{b}$ & $91.37 \pm 3.14^{\mathrm{c}}$ \\
\hline (Z)-3-Hexen-1-ol & $0.12 \pm 0.00^{\mathrm{a}}$ & $0.04 \pm 0.00^{\mathrm{b}}$ & $0.05 \pm 0.00^{c}$ & $0.04 \pm 0.00^{b}$ & $0.20 \pm 0.10^{d}$ \\
\hline 1-Hexanol & $0.49 \pm 0.00^{\mathrm{a}}$ & $0.26 \pm 0.00^{b}$ & $0.23 \pm 0.03^{b}$ & $0.22 \pm 0.00^{b}$ & $0.88 \pm 0.05^{c}$ \\
\hline Metionol & $0.09 \pm 0.00^{\mathrm{a}}$ & $0.37 \pm 0.00^{a b}$ & $0.32 \pm 0.00^{a b}$ & $0.53 \pm 0.20^{b}$ & $0.61 \pm 0.10^{b}$ \\
\hline Benzyl alcohol & $0.17 \pm 0.00^{\mathrm{a}}$ & $0.19 \pm 0.00^{b}$ & $0.27 \pm 0.00^{c}$ & $0.13 \pm 0.00^{\mathrm{d}}$ & $0.15 \pm 0.06^{\mathrm{e}}$ \\
\hline$\beta$-Phenylethyl alcohol & $27.55 \pm 0.05^{\mathrm{a}}$ & $21.27 \pm 2.02^{b}$ & $18.93 \pm 1.04^{b}$ & $23.03 \pm 1.40^{a b}$ & $10.53 \pm 0.29^{c}$ \\
\hline$\sum$ Alcohols & $181.48 \pm 3.37^{a}$ & $171.86 \pm 11.99^{a}$ & $173.94 \pm 0.01^{\mathrm{a}}$ & $181.51 \pm 1.83^{a}$ & $134.13 \pm 4.92^{b}$ \\
\hline Ethyl butyrate & $0.21 \pm 0.03^{\mathrm{a}}$ & $0.30 \pm 0.01^{\mathrm{a}}$ & $0.30 \pm 0.04^{\mathrm{a}}$ & $0.29 \pm 0.03^{\mathrm{a}}$ & $0.31 \pm 0.05^{\mathrm{a}}$ \\
\hline Ethyl isovalerate & $1.35 \pm 0.07^{\mathrm{a}}$ & $0.81 \pm 0.01^{b}$ & $0.98 \pm 0.10^{b}$ & $0.90 \pm 0.06^{b}$ & $0.28 \pm 0.05^{c}$ \\
\hline Ethyl isobutyrate & n.q. & n.q. & n.q. & n.q. & $2.60 \pm 0.37^{\mathrm{a}}$ \\
\hline Isoamyl acetate & $2.07 \pm 0.02^{\mathrm{a}}$ & $1.97 \pm 0.04^{\mathrm{a}}$ & $2.80 \pm 0.00^{b}$ & $1.96 \pm 0.17^{\mathrm{a}}$ & $0.99 \pm 0.05^{\mathrm{c}}$ \\
\hline Ethyl hexanoate & $0.03 \pm 0.00^{\mathrm{a}}$ & $0.21 \pm 0.00^{b}$ & $0.13 \pm 0.03^{a b}$ & $0.20 \pm 0.05^{b}$ & $0.70 \pm 0.06^{c}$ \\
\hline Ethyl-3-hydroxybutyrate & $0.16 \pm 0.00^{\mathrm{a}}$ & $0.57 \pm 0.00^{b}$ & $0.68 \pm 0.00^{c}$ & $0.47 \pm 0.00^{\mathrm{d}}$ & $0.32 \pm 0.06^{\mathrm{e}}$ \\
\hline Hexyl acetate & $0.05 \pm 0.00^{\mathrm{a}}$ & $0.05 \pm 0.00^{\mathrm{a}}$ & $0.06 \pm 0.00^{\mathrm{a}}$ & $0.07 \pm 0.00^{\mathrm{a}}$ & $0.07 \pm 0.05^{\mathrm{a}}$ \\
\hline 2-Phenylethyl acetate & $0.31 \pm 0.01^{\mathrm{a}}$ & $0.28 \pm 0.01^{a}$ & $0.24 \pm 0.09^{a}$ & $0.39 \pm 0.06^{\mathrm{a}}$ & $0.76 \pm 0.09^{b}$ \\
\hline Diethyl succinate & n.q. & $0.09 \pm 0.00^{\mathrm{a}}$ & $0.05 \pm 0.00^{\mathrm{a}}$ & $0.26 \pm 0.08^{b}$ & $6.57 \pm 0.13^{c}$ \\
\hline Ethyl octanoate & $0.06 \pm 0.00^{\mathrm{a}}$ & $0.17 \pm 0.00^{b}$ & $0.21 \pm 0.00^{b}$ & $0.18 \pm 0.04^{b}$ & $0.51 \pm 0.06^{\mathrm{c}}$ \\
\hline Ethyl lactate & $1.71 \pm 0.56^{\mathrm{a}}$ & $8.23 \pm 1.24^{b}$ & $1.73 \pm 0.39^{\mathrm{a}}$ & $5.93 \pm 1.27 \mathrm{bc}$ & $3.32 \pm 0.11^{\mathrm{ac}}$ \\
\hline$\sum$ Esters & $5.98 \pm 0.63^{\mathrm{a}}$ & $12.68 \pm 1.19^{b}$ & $7.19 \pm 0.45^{\mathrm{a}}$ & $10.63 \pm 1.14^{b}$ & $16.43 \pm 1.08^{c}$ \\
\hline Isobutyric acid & $4.86 \pm 0.05^{\mathrm{a}}$ & $4.99 \pm 0.34^{\mathrm{a}}$ & $3.25 \pm 0.07^{b}$ & $4.62 \pm 0.04^{\mathrm{a}}$ & $2.89 \pm 0.05^{b}$ \\
\hline Butyric acid & $0.22 \pm 0.00^{a}$ & $0.29 \pm 0.01^{\mathrm{a}}$ & $0.25 \pm 0.00^{\mathrm{a}}$ & $0.40 \pm 0.14^{\mathrm{a}}$ & $0.23 \pm 0.06^{\mathrm{a}}$ \\
\hline Isovaleric acid & $1.82 \pm 0.03^{a}$ & $1.25 \pm 0.04^{b}$ & $1.29 \pm 0.10^{b}$ & $0.76 \pm 0.01^{\mathrm{c}}$ & $0.74 \pm 0.06^{c}$ \\
\hline Hexanoic acid & $0.90 \pm 0.01^{\mathrm{a}}$ & $2.97 \pm 0.65^{a b c}$ & $2.03 \pm 0.60^{\mathrm{ac}}$ & $5.01 \pm 0.76^{b}$ & $3.11 \pm 0.34^{b c}$ \\
\hline Octanoic acid & $0.41 \pm 0.02^{\mathrm{a}}$ & $1.88 \pm 0.09^{b}$ & $1.26 \pm 0.16^{c}$ & $1.45 \pm 0.15^{\mathrm{c}}$ & $2.18 \pm 0.05^{b}$ \\
\hline Decanoic acid & $0.09 \pm 0.00^{\mathrm{a}}$ & $0.18 \pm 0.06^{\mathrm{a}}$ & $0.07 \pm 0.00^{\mathrm{a}}$ & $0.14 \pm 0.05^{\mathrm{a}}$ & $0.73 \pm 0.09^{b}$ \\
\hline$\sum$ Acids & $8.30 \pm 0.11^{a}$ & $11.57 \pm 0.13^{b c}$ & $8.15 \pm 0.60^{a}$ & $12.37 \pm 1.14^{c}$ & $9.88 \pm 0.65^{a b}$ \\
\hline Diacetyle & $0.58 \pm 0.01^{\mathrm{a}}$ & $0.46 \pm 0.17^{a}$ & $0.51 \pm 0.02^{\mathrm{a}}$ & $0.48 \pm 0.04^{\mathrm{a}}$ & $0.63 \pm 0.09^{a}$ \\
\hline Furfural & n.q. & $0.07 \pm 0.00^{a}$ & $0.04 \pm 0.00^{\mathrm{a}}$ & $0.08 \pm 0.00^{\mathrm{a}}$ & $0.07 \pm 0.05^{\mathrm{a}}$ \\
\hline Benzaldehyde & $0.01 \pm 0.00^{\mathrm{a}}$ & $0.04 \pm 0.00^{a b}$ & $0.06 \pm 0.00^{b}$ & $0.05 \pm 0.01^{b}$ & $0.09 \pm 0.05^{c}$ \\
\hline Phenylacetaldehyde & n.q. & n.q. & n.q. & n.q. & $0.52 \pm 0.05^{\mathrm{a}}$ \\
\hline Acetoin & $5.19 \pm 0.46^{\mathrm{a}}$ & $1.48 \pm 0.01^{b}$ & $3.71 \pm 0.00^{c}$ & $2.30 \pm 0.43^{b}$ & $0.20 \pm 0.10^{\mathrm{d}}$ \\
\hline$\sum$ Aldehydes/Ketones & $5.78 \pm 0.47^{a}$ & $2.04 \pm 0.15^{b}$ & $4.32 \pm 0.02^{c}$ & $2.91 \pm 0.45^{b d}$ & $1.51 \pm 0.34$ be \\
\hline$\gamma$-Butyrolactone & $0.98 \pm 0.00^{a}$ & $6.78 \pm 0.13^{b}$ & $1.64 \pm 0.00^{\mathrm{c}}$ & $5.41 \pm 0.07^{\mathrm{d}}$ & $9.40 \pm 0.10^{\mathrm{e}}$ \\
\hline
\end{tabular}

Data are means \pm standard deviation $(n=2)$. Data with different letters $(\mathrm{a}, \mathrm{b}, \mathrm{c}, \mathrm{d}, \mathrm{e})$ within each row are significantly different (Tukey test; $p<0.05)$. n.q., not quantifiable. (S), sequential culture; (P), pure culture.

A PCA analysis was performed to cluster wines from sequential combinations and the control according to their oenological and aromatic composition. In the score plot for the first two principal components, PC1 and PC2 explain 75.9\% of the total variance (Figure 2). PC1 was mainly determined by ethyl hexanoate (0.986), ethyl octanoate (0.950), decanoic acid (0.944), 2-phenylethyl acetate (0.916), total esters (0.916), 1-propanol (0.916), $\gamma$-butyrolactone (0.903), and alcohol degree (0.831); this component allowed us to differentiate the control $S$. cerevisiae fermentation from those fermentations conducted by sequential non-Saccharomyces/S. cerevisiae combinations. The principal constituents for PC2 were total volatile acids (0.903), butyric acid (0.840), hexanoic acid (0.810), glycerol (0.780), fructose (0.773), and isobutanol (0.740). 
PC2 differentiated the sequential fermentations among them, showing clearly two groups. One group formed by sequential inoculations with W. anomalus 21A-5C/S. cerevisiae CLI 889 and M. guilliermondii CLI 1217/S. cerevisiae CLI 889, mostly related to dry weight, isoamyl alcohol, acetoin, total aldehydes/ketones, isoamyl acetate, ethyl isovalerate, and $\beta$-phenylethyl alcohol in the loadings plot (Figure 2B). Another group contained the sequential cultures with M. pulcherrima strains (CLI 68 and CLI 460), mainly classified by total acids, butyric acid, ethyl lactate, hexanoic acid, glycerol, fructose, and isobutanol.
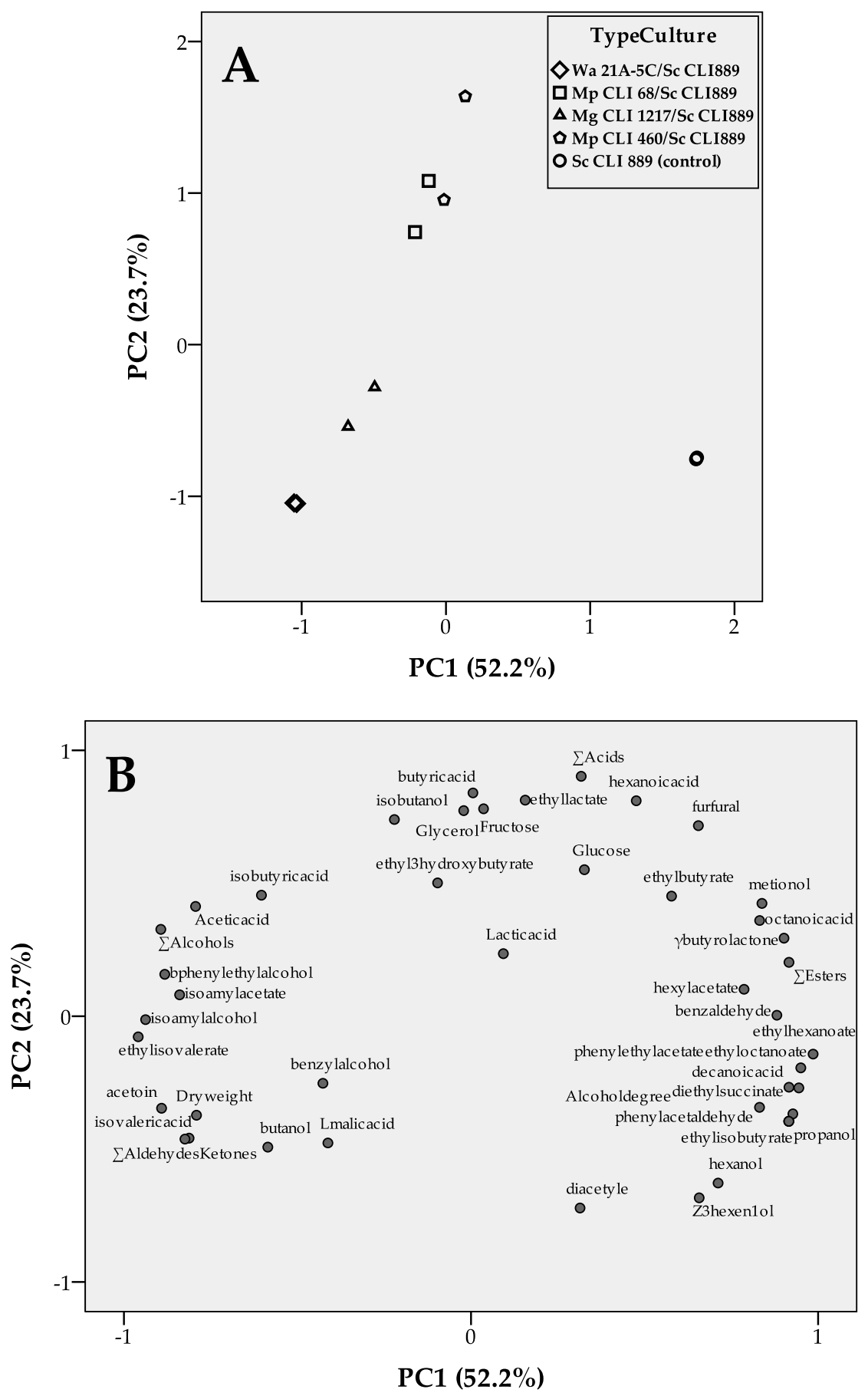

Figure 2. Principal component analysis (PCA) score plot (A) and loadings plot (B) using main fermentation parameters and 32 volatile compounds. 


\section{Discussion}

A combination of quality, health, and economic reasons will force wine producers to find efficient strategies that enable the production of wines with lower ethanol content without detriment on sensory properties. In this work, the strategy employed for this purpose was the use of sequential combinations between non-Saccharomyces and S. cerevisiae yeast strains. It is well documented that non-Saccharomyces strains are often unable to consume all sugar present in a grape must $[13,46]$. Hence, sequential culture application would allow the completion of fermentation using one $S$. cerevisiae strain in a second instance [40,47-49]. The successful trials will be carried out by non-Saccharomyces strains with a low ethanol yield or those that are able to aerobically metabolize sugars without the simultaneous production of ethanol, prior to S. cerevisiae inoculation [2,50]. Regarding aeration regimen, some authors have suggested the use of aerobic yeasts in order to oxide sugars at early stages of winemaking and therefore decrease ethanol production [30,51,52]. After S. cerevisiae inoculation, researchers have favored anaerobic conditions to increase the ethanol yield of Saccharomyces strain and to avoid excessive oxidation of wine. The fermentation procedure programmed in this work was found to have positive results with other authors [50,51,53].

Several studies have evaluated the action of non-Saccharomyces/S. cerevisiae combinations in the reduction of ethanol content in wines [19-22,25-29,50,54]. In some cases, the lower ethanol yields resulted from high residual sugar at the end of fermentation $[20,21,50]$. By contrast, other research works have reported wines with a significant reduction in ethanol yield $(0.6-1.7 \%, v / v)$ when using non-Saccharomyces and S. cerevisiae strains in mixed or sequential cultures. Contreras et al. [22] found that sequential inoculation of a selected M. pulcherrima strain (AWRI1149) with S. cerevisiae wine strain was the best combination for reducing the ethanol content in Chardonnay $(0.9 \%$, v/v lower than control) and Shiraz (1.6\% v/v lower than control) wines. In the same way, Varela et al. [26] obtained Merlot wines fermented with M. pulcherrima with $1.0 \%$ less ethanol than S. cerevisiae-fermented wines at pilot scale. Further studies also showed ethanol reduction using immobilized selected strains of non-Saccharomyces yeasts followed by inoculation of free S. cerevisiae cells [25,47]. The sequential cultures of M. pulcherrima and Starmerella bombicola immobilized cells and S. cerevisiae free cells were the best for ethanol reduction with values $1.4 \%$ and $1.6 \% \mathrm{v} / \mathrm{v}$, respectively [25]. In addition, ethanol lowering has been recorded in wines obtained by different Saccharomyces species. Using sterile Shiraz must, sequential inoculation of M. pulcherrima (AWRI1149) and S. uvarum (AWRI2846) with S. cerevisiae produced wines with $0.9 \% v / v$ less ethanol than S. cerevisiae alone [55]. Puškaš et al. [29] also observed that sequential cultures with M. pulcherrima, S. bayanus, and S. cerevisiae generated wines with $0.9 \%$ v/v lower ethanol than control. In the present work, the application of sequential cultures of native non-Saccharomyces strains (W. anomalus 21A-5C, M. guilliermondii CLI 1217, and M. pulcherrima CLI 68 and CLI 460) and S. cerevisiae CLI 889 generated a reduction of alcohol content between $0.8 \%-1.3 \% v / v$ in Malvar wines, where M. pulcherrima CLI 68/S. cerevisiae CLI 889 sequential inoculation produced the highest decrease in alcohol degree. On the other hand, W. anomalus has been described as low fermentative species in pure culture compared to $S$. cerevisiae $[28,31]$. This statement is consistent with our results where W. anomalus $21 \mathrm{~A}-5 \mathrm{C}$ presented $121 \mathrm{~g} / \mathrm{L}$ of residual sugars after the first $96 \mathrm{~h}$ (Table S1). In sequential culture with $S$. cerevisiae, previous works denoted that the presence of $W$. anomalus does not affect final alcohol contents [28]. Instead, the strain studied in this work (W. anomalus 21A-5C) produced wines with $0.9 \% v / v$ less ethanol than control, in agreement with Contreras et al. [19] who studied another strain of the W. anomalus species. Finally, the use of M. guilliermondii as a low-ethanol producer has not been well documented. Some research works have studied M. guilliermondii as a candidate for reducing ethanol content in wines, but none have considered its use for that purpose [19,56]. In contrast, M. guilliermondii CLI 1217 in sequential culture was the second-best option to decrease the ethanol concentration in Malvar wines (1.2\% less ethanol than control).

Beyond ethanol, the growth of the four selected non-Saccharomyces affected glycerol and acetic acid concentrations in Malvar wines. Several studies have reported that the production of glycerol by yeasts leads to an increase in acetic acid concentration $[57,58]$. Wines produced with $M$. pulcherrima strains 
CLI 68 and CLI 460 contained the greatest glycerol content (8.32 and 9.30 g/L, respectively) compared with other wines studied. The connection between $M$. pulcherrima and an increased glycerol production has been explained by the overexpression of the glycerol-3-phosphate dehydrogenase 1 (GDP1) gene in S. cerevisiae (associated with the conversion of dihydroxyacetone phosphate in glycerol-3-phosphate, an intermediate for glycerol formation). This gene is overinduced when $S$. cerevisiae coexists with $M$. pulcherrima in must fermentations [59]. Moreover, glycerol formation has been demonstrated as the best strategy, followed by yeasts for producing wines with lower ethanol content [60]. This compound is present in semi-sweet and dry wines ranging from 5 to $14 \mathrm{~g} / \mathrm{L}$, although glycerol imparts sweetness at a threshold of about $5.2 \mathrm{~g} / \mathrm{L}$ in dry white wines [61]. Unlike glycerol, acetic acid imparts an objectionable character to wine at elevated concentrations. This volatile acid becomes undesirable at concentrations over $0.7-1.1 \mathrm{~g} / \mathrm{L}$, depending on the style of wine; its optimal concentration is 0.2-0.7 $\mathrm{g} / \mathrm{L}$ [61]. One reason for elevated acetic acid levels is usually related to aeration, which could lead to elevated oxygen levels during fermentation [23,30,52]. However, more acetic acid was produced in Malvar wines during the anaerobic period than during aerobic fermentation in the current work, in agreement with results observed by Röcker et al. [24]. All sequential fermentation between four selected non-Saccharomyces/S. cerevisiae in this article produced wines with elevated volatile acidity ( $>0.7 \mathrm{~g} / \mathrm{L}$ of acetic acid), significantly increased after $S$. cerevisiae inoculation (Table S1, see values of acetic acid caused by non-Sacharomyces fermentations). This noticeable increase could be caused by a lack of nutrition sources available for $S$. cerevisiae in the second part of fermentations [62,63]. Low YAN values (below $200 \mathrm{mg} \mathrm{N} / \mathrm{L}$, such as the Malvar must we studied) can also lead to elevated acetic acid concentration [64].

For selection of low-ethanol producing wine yeast, its impact on aroma profile is of great importance. Sequential cultures in this work had an important influence on higher alcohol proportions compared with the control. High levels of these volatile compounds ( $>300 \mathrm{mg} / \mathrm{L}$ ) can have a detrimental effect on wine aroma, while concentrations below $300 \mathrm{mg} / \mathrm{L}$ can contribute positively to aroma complexity [65,66]. All wines produced using sequential inoculations presented values of higher alcohols below $300 \mathrm{mg} / \mathrm{L}$.

It is worth noting that isoamyl alcohol (harsh, bitter) and $\beta$-phenylethyl alcohol (flowery, roses) are increased by sequential culture with W. anomalus 21A-5C and M. guilliermondii CLI 1217 strains. The ethyl isovalerate and isoamyl acetate esters, which impart fruity (banana) and sweet aromas, were also higher in these sequential cultures. In relation with $W$. anomalus species, these results agree with other publications [28,67-70]. Rojas et al. [67] indicated that one W. anomalus (P. anomala) strain produced the highest isoamyl acetate concentration in $48 \mathrm{~h}$ cultures in aerobiosis conditions; moreover, the increment in acetates was also observed in sequential cultures with W. anomalus and S. cerevisiae [28,70]. In addition to increasing alcohols, as well as ethyl and acetate esters [69], Airen white wines elaborated with $W$. anomalus/S. cerevisiae sequential cultures were judged to be better than $S$. cerevisiae monoculture due to their higher scores for descriptors as fruity and floral, and having an intense sweet smell and longer-lasting aftertaste [68]. Nevertheless, M. guilliermondii has been considered as a spoilage yeast in winemaking that is able to produce large amounts of volatile phenols [71], identified with horse, stable, leather, or medicinal notes [72]; in contrast, the $M$. guilliermondii CLI 1217 strain used in sequential culture in the present work has contributed to rising amounts of fusel alcohols and some esters related to fruity and floral character in Malvar white wines.

Apart from high levels of isoamyl alcohol and $\beta$-phenylethyl alcohol previously documented by authors [22,24,73-75], sequential cultures with M. pulcherrima strains (CLI 68 and CLI 460) also showed an elevated proportion of isobutanol (bitter, fusel, alcohol) compared to the wine fermented solely with $S$. cerevisiae. This high isobutanol content is in good agreement with the experimental data reported previously [24,28,76]. While some reports [22,73,77] have stated that wines inoculated with $M$. pulcherrima/S. cerevisiae contain higher concentration of esters, other studies $[16,54,74,78,79]$ have noted that wines fermented with these yeast species in combination have lower concentrations, as in the case of this work. Moreover, it is worth mentioning that sequential culture with M. pulcherrima native strains presented higher concentration of esters with fruity aroma (ethyl isovalerate, isoamyl acetate 
and ethyl-3-hydroxybutyrate) than the control. On the other hand, Malvar wines elaborated with $M$. pulcherrima CLI 68 and CLI 460 strains are mostly related to volatile fatty acids. These compounds are generally associated with negative aromas in wine [80], although hexanoic, octanoic, and decanoic fatty acids impart mild and pleasant notes to wine at concentrations between 4 to $10 \mathrm{mg} / \mathrm{L}$; however, their impact can be negative on wine at levels above $20 \mathrm{mg} / \mathrm{L}$ [81]. Thus, these fatty acids might have a positive effect on the aroma of M. pulcherrima/S. cerevisiae Malvar wines since their levels are below $20 \mathrm{mg} / \mathrm{L}$.

Relative to wine fermented with the control, S. cerevisiae CLI 889, we found a higher total concentration of esters in Malvar wines using S. cerevisiae monoculture. This S. cerevisiae strain produced wines with a fruity and floral character due to the greater concentration of ethyl isobutyrate (pineapple), ethyl hexanoate (pineapple, apple), and 2-phenylethyl acetate (flowery, lilac) esters, being the perfect candidate to ferment Malvar musts, and improving the typicity of the wines produced in the area "Vinos de Madrid".

\section{Conclusions}

The present results indicated that sequential cultures of native non-Saccharomyces (W. anomalus 21A-5C, M. guilliermondii CLI 1217, and M. pulcherrima CLI 68 and CLI 460) with S. cerevisiae CLI 889 can be used as a strategy to reduce the ethanol levels in wines, whilst keeping the wine typicity of the area. These combinations could have a positive impact on glycerol content and the volatile profile of these wines, showing W. anomalus 21A-5C and M. guilliermondii CLI 1217 combinations with S. cerevisiae being mostly related to fruity and floral aroma compounds when compared with $M$. pulcherrima usage. However, further optimization will be required to control the acetic acid production in all sequential fermentations. Future work will focus on fermentations at a pilot scale through using the selected strains and having a second inoculation at different times, which will allow for the evaluation of the sensorial profile of the resulting wines.

Supplementary Materials: The following are available online at http://www.mdpi.com/2311-5637/6/2/60/s1, Table S1. Volatile acidity (as g/L of acetic acid), reducing sugars (glucose + fructose, g/L), and dry weight (mg) of wines after Section I (pure culture of non-Saccharomyces strains and the control under aerobic conditions).

Author Contributions: Investigation, M.G. and T.A.; methodology, M.G. and T.A.; formal analysis, M.G., B.E.-Z., J.M.C., and T.A.; writing - original draft preparation, M.G. and T.A.; writing-review and editing, M.G., B.E.-Z., J.M.C., and T.A. All authors have read and agreed to the published version of the manuscript.

Funding: This work was financially supported by the project RM2010-00009-C03-01 funded by the Instituto Nacional de Investigación y Tecnología Agraria y Alimentaria (INIA).

Conflicts of Interest: The authors declare no conflict of interest. The funders had no role in the design of the study; in the collection, analyses, or interpretation of data; in the writing of the manuscript; and in the decision to publish the results.

\section{References}

1. Mira de Orduña, R. Climate change associated effects on grape and wine quality and production. Food Res. Int. 2010, 43, 1844-1855. [CrossRef]

2. Gonzalez, R.; Quirós, M.; Morales, P. Yeast respiration of sugars by non-Saccharomyces yeast species: A promising and barely explored approach to lowering alcohol content of wines. Trends Food Sci. Technol. 2013, 29, 55-61. [CrossRef]

3. Liguori, L.; Russo, P.; Albanese, D.; Di Matteo, M. Production of low-alcohol beverages: Current status and perspectives. In Food Processing for Increased Quality and Consumption; Grumezescu, A., Holban, A.M., Eds.; Elsevier Inc.: Amsterdam, The Netherlands, 2018; pp. 347-382. ISBN 9780128114476.

4. Stockley, C.S.; Varela, C.; Coulter, A.; Dry, P.R.; Francis, I.L.; Muhlack, R.; Pretorius, I.S. Controlling the Highs and the Lows of Alcohol in Wine; Nova Science Publishers, Inc.: New York, NY, USA, 2012; ISBN 9781614706359.

5. Varela, C.; Dry, P.R.; Kutyna, D.R.; Francis, I.L.; Henschke, P.A.; Curtin, C.D.; Chambers, P.J. Strategies for reducing alcohol concentration in wine. Aust. J. Grape Wine Res. 2015, 21, 670-679. [CrossRef] 
6. Fischer, U.; Noble, A. The effect of ethanol, catechin concentration, and $\mathrm{pH}$ on sourness and bitterness of wine. Am. J. Enol. Vitic. 1994, 45, 6-10.

7. Wilkinson, K.L.; Jiranck, V. Wine of reduced alcohol content: Consumer and society demand vs. industry willingness and ability to deliver. In 1st International Symposium Alcohol Level Reduction in Wine; Institut des Sciences de la Vigne et du Vin: Villenave d'Ornon CEDEX, France, 2013; pp. 98-104.

8. Stockwell, T.; Zhao, J.; Panwar, S.; Roemer, A.; Naimi, T.; Chikritzhs, T. Do "moderate" drinkers have reduced mortality risk? A systematic review and meta-analysis of alcohol consumption and all-cause mortality. J. Stud. Alcohol Drugs 2016, 77, 185-198. [CrossRef]

9. Sharma, A.; Vandenberg, B.; Hollingsworth, B. Minimum pricing of alcohol versus volumetric taxation: Which policy will reduce heavy consumption without adversely affecting light and moderate consumers? PLoS ONE 2014, 9, e80936. [CrossRef]

10. Ciani, M.; Morales, P.; Comitini, F.; Tronchoni, J.; Canonico, L.; Curiel, J.A.; Oro, L.; Rodrigues, A.J.; Gonzalez, R. Non-conventional yeast species for lowering ethanol content of wines. Front. Microbiol. 2016, 7, 642. [CrossRef]

11. Rolle, L.; Englezos, V.; Torchio, F.; Cravero, F.; Río Segade, S.; Rantsiou, K.; Giacosa, S.; Gambuti, A.; Gerbi, V.; Cocolin, L. Alcohol reduction in red wines by technological and microbiological approaches: A comparative study. Aust. J. Grape Wine Res. 2017, 24, 62-74. [CrossRef]

12. Tilloy, V.; Ortiz-Julien, A.; Dequin, S. Reduction of ethanol yield and improvement of glycerol formation by adaptive evolution of the wine yeast Saccharomyces cerevisiae under hyperosmotic conditions. Appl. Environ. Microbiol. 2014, 80, 2623-2632. [CrossRef]

13. Fleet, G.H.; Heard, G.M. Yeast growth during fermentation. In Wine Microbiology and Biotechnology; Fleet, G.H., Ed.; Harwood Academic Publishers: Chur, Switzerland, 1993; pp. 27-54.

14. Andorrà, I.; Berradre, M.; Rozès, N.; Mas, A.; Guillamón, J.M.; Esteve-Zarzoso, B. Effect of pure and mixed cultures of the main wine yeast species on grape must fermentations. Eur. Food Res. Technol. 2010, 231, 215-224. [CrossRef]

15. Cominiti, F.; Gobbi, M.; Domizio, P.; Romani, C.; Lencioni, L.; Mannazzu, I.; Ciani, M. Selected non-Saccharomyces wine yeasts in controlled multistarter fermentations with Saccharomyces cerevisiae. Food Microbiol. 2011, 28, 873-882. [CrossRef]

16. García, M.; Arroyo, T.; Crespo, J.; Cabellos, J.M.; Esteve-Zarzoso, B. Use of native non-Saccharomyces strain: A new strategy in D.O. "Vinos de Madrid" (Spain) wines elaboration. Eur. J. Food Sci. Technol. 2017, 5, 1-31.

17. Dutraive, O.; Benito, S.; Fritsch, S.; Beisert, B.; Patz, C.; Rauhut, D. Effect of sequential inoculation with non-Saccharomyces and Saccharomyces yeasts on Riesling wine chemical composition. Fermentation 2019, 5, 79. [CrossRef]

18. Cuello, R.A.; Flores Montero, K.J.; Mercado, L.A.; Combina, M.; Ciklic, I.F. Construction of low-ethanol-wine yeasts through partial deletion of the Saccharomyces cerevisiae PDC2 gene. AMB Express 2017, 7, 67. [CrossRef]

19. Contreras, A.; Hidalgo, C.; Schmidt, S.; Henschke, P.A.; Curtin, C.; Varela, C. The application of non-Saccharomyces yeast in fermentations with limited aeration as a strategy for the production of wine with reduced alcohol content. Int. J. Food Microbiol. 2015, 205, 7-15. [CrossRef]

20. Ciani, M.; Beco, L.; Comitini, F. Fermentation behaviour and metabolic interactions of multistarter wine yeast fermentations. Int. J. Food Microbiol. 2006, 108, 239-245. [CrossRef]

21. Magyar, I.; Tóth, T. Comparative evaluation of some oenological properties in wine strains of Candida stellata, Candida zemplinina, Saccharomyces uvarum and Saccharomyces cerevisiae. Food Microbiol. 2011, 28, 94-100. [CrossRef]

22. Contreras, A.; Hidalgo, C.; Henschke, P.A.; Chambers, P.J.; Curtin, C.; Varela, C. Evaluation of non-Saccharomyces yeasts for the reduction of alcohol content in wine. Appl. Environ. Microbiol. 2014, 80, 1670-1678. [CrossRef]

23. Morales, P.; Rojas, V.; Quirós, M.; Gonzalez, R. The impact of oxygen on the final alcohol content of wine fermented by a mixed starter culture. Appl. Microbiol. Biotechnol. 2015, 99, 3993-4003. [CrossRef]

24. Röcker, J.; Strub, S.; Ebert, K.; Grossmann, M. Usage of different aerobic non-Saccharomyces yeasts and experimental conditions as a tool for reducing the potential ethanol content in wines. Eur. Food Res. Technol. 2016, 242, 2051-2070. [CrossRef]

25. Canonico, L.; Comitini, F.; Oro, L.; Ciani, M. Sequential fermentation with selected immobilized non-Saccharomyces yeast for reduction of ethanol content in wine. Front. Microbiol. 2016, 7, 278. [CrossRef] 
26. Varela, C.; Barker, A.; Tran, T.; Borneman, A.; Curtin, C. Sensory profile and volatile aroma composition of reduced alcohol Merlot wines fermented with Metschnikowia pulcherrima and Saccharomyces uvarum. Int. J. Food Microbiol. 2017, 252, 1-9. [CrossRef]

27. Canonico, L.; Comitini, F.; Ciani, M. Metschnikowia pulcherrima selected strain for ethanol reduction in wine: Influence of cell immobilization and aeration condition. Foods 2019, 8, 378. [CrossRef]

28. Aplin, J.J.; White, K.P.; Edwards, C.G. Growth and metabolism of non-Saccharomyces yeasts isolated from Washington state vineyards in media and high sugar grape musts. Food Microbiol. 2019, 77, 158-165. [CrossRef]

29. Puškaš, V.S.; Miljić, U.D.; Djuran, J.J.; Vučurović, V.M. The aptitude of commercial yeast strains for lowering the ethanol content of wine. Food Sci. Nutr. 2020, 8, 278. [CrossRef]

30. Quirós, M.; Rojas, V.; Gonzalez, R.; Morales, P. Selection of non-Saccharomyces yeast strains for reducing alcohol levels in wine by sugar respiration. Int. J. Food Microbiol. 2014, 181, 85-91. [CrossRef]

31. Cordero-Bueso, G.; Esteve-Zarzoso, B.; Cabellos, J.M.; Gil-Díaz, M.; Arroyo, T. Biotechnological potential of non-Saccharomyces yeasts isolated during spontaneous fermentations of Malvar (Vitis vinifera cv. L.). Eur. Food Res. Technol. 2013, 236, 193-207. [CrossRef]

32. Gil, M.; Cabellos, J.M.; Arroyo, T.; Prodanov, M. Characterization of the volatile fraction of young wines from the Denomination of Origin "Vinos de Madrid" (Spain). Anal. Chim. Acta 2006, 563, 145-153. [CrossRef]

33. Tello, J.; Cordero-Bueso, G.; Aporta, I.; Cabellos, J.M.; Arroyo, T. Genetic diversity in commercial wineries: Effects of the farming system and vinification management on wine yeasts. J. Appl. Microbiol. 2012, 112, 302-315. [CrossRef]

34. Cordero-Bueso, G.; Esteve-Zarzoso, B.; Gil-Díaz, M.; García, M.; Cabellos, J.; Arroyo, T. Improvement of Malvar wine quality by use of locally-selected Saccharomyces cerevisiae strains. Fermentation 2016, $2,7$. [CrossRef]

35. Merloni, E.; Camanzi, L.; Mulazzani, L.; Malorgio, G. Adaptive capacity to climate change in the wine industry: A Bayesian Network approach. Wine Econ. Policy 2018, 7, 165-177. [CrossRef]

36. Arroyo, T.; Cordero, G.; Serrano, A.; Valero, E. $\beta$-Glucosidase production by non-Saccharomyces yeasts isolated from vineyard. In Expression of Multidisciplinary Flavour Science; Blank, I., Wüst, M., Yeretzian, C., Eds.; Institute of Chemistry and Biological Chemistry: Winterthur, Switzerland, 2010; pp. 359-362.

37. Arroyo, T. Estudio de la Influencia de Diferentes Tratamientos Enológicos en la Evolución de la Microbiota y en la Calidad de los vinos Elaborados con la Variedad "Airén", en la D.O. “Vinos de Madrid". Ph.D. Thesis, University of Alcalá, Madrid, Spain, 2000.

38. Esteve-Zarzoso, B.; Belloch, C.; Uruburu, F.; Querol, A. Identification of yeasts by RFLP analysis of the 5.8S rRNA gene and the two ribosomal internal transcribed spacers. Int. J. Syst. Bacteriol. 1999, 49, 329-337. [CrossRef] [PubMed]

39. Cordero-Bueso, G.; Arroyo, T.; Serrano, A.; Tello, J.; Aporta, I.; Vélez, M.D.; Valero, E. Influence of the farming system and vine variety on yeast communities associated with grape berries. Int. J. Food Microbiol. 2011, 145, 132-139. [CrossRef] [PubMed]

40. García, M.; Esteve-Zarzoso, B.; Crespo, J.; Cabellos, J.M.; Arroyo, T. Yeast monitoring of wine mixed or sequential fermentations made by native strains from D.O. "Vinos de Madrid" using real-time quantitative PCR. Front. Microbiol. 2017, 8, 2520. [CrossRef] [PubMed]

41. Kurtzman, C.P.; Robnett, C.J. Identification and phylogeny of ascomycetous yeasts from analysis of nuclear large subunit (26S) ribosomal DNA partial sequences. Antonie Van Leeuwenhoek 1998, 73, 331-371. [CrossRef]

42. García, M.; Greetham, D.; Wimalasena, T.T.; Phister, T.G.; Cabellos, J.M.; Arroyo, T. The phenotypic characterization of yeast strains to stresses inherent to wine fermentation in warm climates. J. Appl. Microbiol. 2016, 121, 215-233. [CrossRef] [PubMed]

43. García, M.; Apolinar-Valiente, R.; Williams, P.; Esteve-Zarzoso, B.; Arroyo, T.; Crespo, J.; Doco, T. Polysaccharides and oligosaccharides produced on Malvar wines elaborated with Torulaspora delbrueckii CLI 918 and Saccharomyces cerevisiae CLI 889 native yeasts from D.O. "Vinos de Madrid.". J. Agric. Food Chem. 2017, 65, 6656-6664. [CrossRef]

44. Ortega, C.; López, R.; Cacho, J.; Ferreira, V. Fast analysis of important wine volatile compounds-Development and validation of a new method based on gas chromatographic-flame ionisation detection analysis of dichloromethane microextracts. J. Chromatogr. A 2001, 923, 205-214. [CrossRef] 
45. Balboa-Lagunero, T.; Arroyo, T.; Cabellos, J.M.; Aznar, M. Yeast selection as a tool for reducing key oxidation notes in organic wines. Food Res. Int. 2013, 53, 252-259. [CrossRef]

46. Fleet, G.H. Wine. In Food Microbiology: Fundamentals and Frontiers; Doyle, M.P., Beuchat, L.R., Eds.; ASM Press: Washington, DC, USA, 2007; pp. 863-890.

47. Ciani, M.; Canonico, L.; Oro, L.; Comitini, F. Sequential fermentation using non-Saccharomyces yeasts for the reduction of alcohol content in wine. BIOWeb Conf. 2014, 3, 02015. [CrossRef]

48. Loira, I.; Vejarano, R.; Bañuelos, M.A.; Morata, A.; Tesfaye, W.; Uthurry, C.; Villa, A.; Cintora, I.; Suárez-Lepe, J.A. Influence of sequential fermentation with Torulaspora delbrueckii and Saccharomyces cerevisiae on wine quality. LWT Food Sci. Technol. 2014, 59, 915-922. [CrossRef]

49. Vilela, A. Modulating wine pleasantness throughout wine-yeast co-inoculation or sequential inoculation. Fermentation 2020, 6, 22. [CrossRef]

50. Ciani, M.; Ferraro, L. Enhanced glycerol content in wines made with immobilized Candida stellata cells. Appl. Environ. Microbiol. 1996, 62, 128-132. [CrossRef] [PubMed]

51. Erten, H.; Campbell, I. The production of low-alcohol wines by aerobic yeasts. J. Inst. Brew. 2001, 107, 207-215. [CrossRef]

52. Rodrigues, A.J.; Raimbourg, T.; Gonzalez, R.; Morales, P. Environmental factors influencing the efficacy of different yeast strains for alcohol level reduction in wine by respiration. LWT Food Sci. Technol. 2016, 65, 1038-1043. [CrossRef]

53. Ferraro, L.; Fatichenti, F.; Ciani, M. Pilot scale vinification process using immobilized Candida stellata cells and Saccharomyces cerevisiae. Process Biochem. 2000, 35, 1125-1129. [CrossRef]

54. Canonico, L.; Solomon, M.; Comitini, F.; Ciani, M.; Varela, C. Volatile profile of reduced alcohol wines fermented with selected non-Saccharomyces yeasts under different aeration conditions. Food Microbiol. 2019, 84, 103247. [CrossRef]

55. Contreras, A.; Curtin, C.; Varela, C. Yeast population dynamics reveal a potential "collaboration" between Metschnikowia pulcherrima and Saccharomyces uvarum for the production of reduced alcohol wines during Shiraz fermentation. Appl. Microbiol. Biotechnol. 2014, 99, 1885-1895. [CrossRef]

56. Mestre Furlani, M.V.; Maturano, Y.P.; Combina, M.; Mercado, L.A.; Toro, M.E.; Vazquez, F. Selection of non-Saccharomyces yeasts to be used in grape musts with high alcoholic potential: A strategy to obtain wines with reduced ethanol content. FEMS Yeast Res. 2017, 17, 1-10. [CrossRef] [PubMed]

57. Remize, F.; Roustan, J.L.; Sablayrolles, J.M.; Barre, P.; Dequin, S. Glycerol overproduction by engineered Sacharomyces cerevisiae wine yeast strains leads to substantial changes in by-product formation and to a stimulation of fermentation rate in stationary phase. Appl. Environ. Microbiol. 1999, 65, 143-149. [CrossRef]

58. Eglinton, J.M.; Heinrich, A.J.; Pollnitz, A.P.; Langridge, P.; Henschke, P.A.; De Barros Lopes, M. Decreasing acetic acid accumulation by a glycerol overproducing strain of Saccharomyces cerevisiae by deleting the ALD6 aldehyde dehydrogenase gene. Yeast 2002, 19, 295-301. [CrossRef] [PubMed]

59. Sadoudi, M.; Rousseaux, S.; David, V.; Alexandre, H.; Tourdot-Maréchal, R. Metschnikowia pulcherrima influences the expression of genes involved in PDH bypass and glyceropyruvic fermentation in Saccharomyces cerevisiae. Front. Microbiol. 2017, 8, 1137. [CrossRef]

60. Varela, C.; Kutyna, D.R.; Solomon, M.R.; Black, C.A.; Borneman, A.; Henschke, P.A.; Pretorius, I.S.; Chambers, P.J. Evaluation of gene modification strategies for the development of low-alcohol-wine yeasts. Appl. Environ. Microbiol. 2012, 78, 6068-6077. [CrossRef] [PubMed]

61. Swiegers, J.H.; Bartowsky, E.J.; Henschke, P.A.; Pretorius, I.S. Yeast and bacterial modulation of wine aroma and flavour. Aust. J. Grape Wine Res. 2005, 11, 139-173. [CrossRef]

62. Beltran, G.; Esteve-Zarzoso, B.; Rozès, N.; Mas, A.; Guillamón, J.M. Influence of the timing of nitrogen additions during synthetic grape must fermentations on fermentation kinetics and nitrogen consumption. J. Agric. Food Chem. 2005, 53, 996-1002. [CrossRef] [PubMed]

63. Medina, K.; Boido, E.; Dellacassa, E.; Carrau, F. Growth of non-Saccharomyces yeasts affects nutrient availability for Saccharomyces cerevisiae during wine fermentation. Int. J. Food Microbiol. 2012, 157, 245-250. [CrossRef]

64. Vilanova, M.; Ugliano, M.; Varela, C.; Siebert, T.; Pretorius, I.S.; Henschke, P.A. Assimilable nitrogen utilisation and production of volatile and non-volatile compounds in chemically defined medium by Saccharomyces cerevisiae wine yeasts. Appl. Microbiol. Biotechnol. 2007, 77, 145-157. [CrossRef]

65. Styger, G.; Prior, B.; Bauer, F.F. Wine flavor and aroma. J. Ind. Microbiol. Biotechnol. 2011, 38, 1145-1159. [CrossRef] 
66. Belda, I.; Ruiz, J.; Esteban-Fernández, A.; Navascués, E.; Marquina, D.; Santos, A.; Moreno-Arribas, M.V. Microbial contribution to wine aroma and its intended use for wine quality improvement. Molecules 2017, 22, 189. [CrossRef]

67. Rojas, V.; Gil, J.V.; Piñaga, F.; Manzanares, P. Studies on acetate ester production by non-Saccharomyces wine yeasts. Int. J. Food Microbiol. 2001, 70, 283-289. [CrossRef]

68. Izquierdo Cañas, P.M.; Palacios García, A.T.; García Romero, E. Enhancement of flavour properties in wines using sequential inoculations of non-Saccharomyces (Hansenula and Torulaspora) and Saccharomyces yeast starter. Vitis 2011, 50, 177-182.

69. Domizio, P.; Romani, C.; Lencioni, L.; Comitini, F.; Gobbi, M.; Mannazzu, I.; Ciani, M. Outlining a future for non-Saccharomyces yeasts: Selection of putative spoilage wine strains to be used in association with Saccharomyces cerevisiae for grape juice fermentation. Int. J. Food Microbiol. 2011, 147, 170-180. [CrossRef] [PubMed]

70. Izquierdo Cañas, P.M.; García-Romero, E.; Heras Manso, J.M.; Fernández-González, M. Influence of sequential inoculation of Wickerhamomyces anomalus and Saccharomyces cerevisiae in the quality of red wines. Eur. Food Res. Technol. 2014, 239, 279-286. [CrossRef]

71. Sáez, J.S.; Lopes, C.A.; Kirs, V.C.; Sangorrín, M.P. Enhanced volatile phenols in wine fermented with Saccharomyces cerevisiae and spoiled with Pichia guilliermondii and Dekkera bruxellensis. Lett. Appl. Microbiol. 2010, 51, 170-176. [CrossRef]

72. Suárez, R.; Suárez-Lepe, J.A.; Morata, A.; Calderón, F. The production of ethylphenols in wine by yeasts of the genera Brettanomyces and Dekkera: A review. Food Chem. 2007, 102, 10-21. [CrossRef]

73. Sadoudi, M.; Tourdot-Maréchal, R.; Rousseaux, S.; Steyer, D.; Gallardo-Chacón, J.J.; Ballester, J.; Vichi, S.; Guérin-Schneider, R.; Caixach, J.; Alexandre, H. Yeast-yeast interactions revealed by aromatic profile analysis of Sauvignon Blanc wine fermented by single or co-culture of non-Saccharomyces and Saccharomyces yeasts. Food Microbiol. 2012, 32, 243-253. [CrossRef]

74. González-Royo, E.; Pascual, O.; Kontoudakis, N.; Esteruelas, M.; Esteve-Zarzoso, B.; Mas, A.; Canals, J.M.; Zamora, F. Oenological consequences of sequential inoculation with non-Saccharomyces yeasts (Torulaspora delbrueckii or Metschnikowia pulcherrima) and Saccharomyces cerevisiae in base wine for sparkling wine production. Eur. Food Res. Technol. 2015, 240, 999-1012. [CrossRef]

75. Gobert, A.; Tourdot-Maréchal, R.; Morge, C.; Sparrow, C.; Liu, Y.; Quintanilla-Casas, B.; Vichi, S.; Alexandre, H. Non-Saccharomyces yeasts nitrogen source preferences: Impact on sequential fermentation and wine volatile compounds profile. Front. Microbiol. 2017, 8, 2175. [CrossRef]

76. Seguinot, P.; Ortiz-Julien, A.; Camarasa, C. Impact of nutrient availability on the fermentation and production of aroma compounds under sequential inoculation with M. pulcherrima and S. cerevisiae. Front. Microbiol. 2020, 11, 305. [CrossRef]

77. Rodríguez, M.E.; Lopes, C.A.; Barbagelata, R.J.; Barda, N.B.; Caballero, A.C. Influence of Candida pulcherrima Patagonian strain on alcoholic fermentation behaviour and wine aroma. Int. J. Food Microbiol. 2010, 138, 19-25. [CrossRef]

78. Varela, C.; Sengler, F.; Solomon, M.; Curtin, C. Volatile flavour profile of reduced alcohol wines fermented with the non-conventional yeast species Metschnikowia pulcherrima and Saccharomyces uvarum. Food Chem. 2016, 209, 57-64. [CrossRef]

79. Ruiz, J.; Belda, I.; Beisert, B.; Navascués, E.; Marquina, D.; Calderón, F.; Rauhut, D.; Santos, A.; Benito, S. Analytical impact of Metschnikowia pulcherrima in the volatile profile of Verdejo white wines. Appl. Microbiol. Biotechnol. 2018, 102, 8501-8509. [CrossRef]

80. Lambrechts, M.G.; Pretorius, I.S. Yeast and its importance to wine aroma-A review. South African J. Enol. Vitic. 2000, 21, 97-129. [CrossRef]

81. Jiang, B.; Zhang, Z. Volatile compounds of young wines from Cabernet Sauvignon, Cabernet Gernischet and Chardonnay varieties grown in the Loess Plateau region of China. Molecules 2010, 15, 9184-9196. [CrossRef]

(C) 2020 by the authors. Licensee MDPI, Basel, Switzerland. This article is an open access article distributed under the terms and conditions of the Creative Commons Attribution (CC BY) license (http://creativecommons.org/licenses/by/4.0/). 